\title{
Protective Effect of 2-Dodecyl-6- Methoxycyclohexa-2, 5-Diene-1, 4-Dione, Isolated from Averrhoa Carambola $L .$, Against Palmitic Acid-Induced Inflammation and Apoptosis in Min6 Cells by Inhibiting the TLR4-MyD88-NF- $\kappa B$ Signaling Pathway
}

Qiuqiao Xie Shijun Zhang Chunxia Chen Juman Li Xiaojie Wei

Xiaohui Xu Feifei Xuan Ning Chen Thithaihoa Pham Ni Qin Junhui He

Fangxing Ye Wansu Huang Renbin Huang Qingwei Wen

Pharmaceutical College, Guangxi Medical University, Nanning, Guangxi, China

Key Words

DMDD • Min6 cell $\bullet$ Inflammation $•$ Apoptosis $•$ TLR4 $\bullet$ MyD88 $\bullet N F-\kappa B$

\begin{abstract}
Background/Aims: Studies have demonstrated that 2-dodecyl-6-methoxycyclohexa-2, 5-diene-1, 4-dione (DMDD), isolated from the roots of Averrhoa carambola L., has significant therapeutic potential for the treatment of diabetes. However, the protective effect of DMDD against pancreatic beta cell dysfunction has never been reported. We investigated whether DMDD protected against palmitic acid-induced dysfunction in pancreatic $\beta$-cell line Min 6 cells by attenuating the inflammatory response and apoptosis and to shed light on its possible mechanism. Methods: Cell viability was assessed by CCK-8. Glucose-stimulated insulin secretion levels and inflammatory cytokines levels were examined by ELISA. Apoptosis was assessed by Annexin V-FITC/PI Flow cytometry assay, Hoechst 33342/PI double-staining assay, and Transmission electron microscopy assay. Relative quantitative real-time PCR and western blot were used to determine the expressions of genes and proteins. Results: Cell viability and glucose-stimulated insulin secretion levels were increased in DMDD-pretreated Min6 cells. DMDD inhibited inflammatory cytokines IL-6, TNF- $\alpha$ and MCP-1 generations in palmitic acid (PA)-induced Min6 cells. Moreover, DMDD protected against PA-induced Min6 cells apoptosis and the expression of Cleaved-Caspase-3,-8 and -9 were down-regulated and the $\mathrm{Bcl}-2 / \mathrm{Bax}$ ratio was increased in DMDD-pretreated Min6 cells. In addition, the expression of TLR4, MyD88 and NF- $\kappa$ B were down-regulated in DMDD-pretreated Min6 cells and TAK242-pretreated group cells. Conclusions: DMDD protected Min6 cells against PA-induced dysfunction by attenuating the inflammatory response and apoptosis, and its mechanism of this protection was associated with inhibiting the TLR4-MyD88-NF- $\kappa$ B signaling pathway.
\end{abstract}

Q. Xie and S. Zhang these authors contributed equally to this work.

(C) 2016 The Author(s)

Published by S. Karger AG, Basel

Renbin Huang and Qingwei Wen

Pharmaceutical College, Guangxi Medical University, 22, Shuangyong Road, Nanning, Guangxi, 530021 (PR China)

Tel.+86-0771-5339805, E-Mail huangrenbin518@163.com / wqw760623@163.com 


\section{Cellular Physiology Cell Physiol Biochem 2016;39:1705-1715

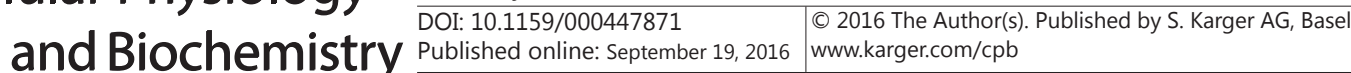 \\ Xie et al.: Protective Effects of DMDD on Min6 Cells Dysfunction}

\section{Introduction}

Many complications result from the metabolic disorders of pancreatic $\beta$-cell dysfunction [1]. Inflammation and apoptosis play crucial roles in the progression of pancreatic $\beta$-cell dysfunction [2].

Many studies have demonstrated that decreases in pro-inflammatory cytokines that contribute to pancreatic $\beta$-cell dysfunction, such as IL-6, TNF- $\alpha$ and MCP-1 have a beneficial effect on pancreatic $\beta$-cell dysfunction [3]. TLR4 is an important molecular receptor in innate immunity and inflammatory responses. TLR4 is directly activated by palmitic acid (PA), one of free fatty acids, resulting in the activation of the distinct adaptor protein MyD88. MyD88-dependent signaling pathway leads to the release of NF- $\kappa \mathrm{B}$ from $\mathrm{I} \kappa \mathrm{B} \alpha$, resulting in the increased levels of downstream inflammatory cytokines [4]. Apoptosis also plays a crucial role in the progression of pancreatic $\beta$-cell dysfunction. Apoptosis involves two major pathways, the extrinsic and intrinsic [5]. The extrinsic pathway, also known as the death receptor pathway, initiates the Cleaved-Caspase-8 dependent signal cascade [6]. The intrinsic pathway, also known as the mitochondrial pathway, involves the release of apoptotic proteins, such as cytochrome c, Cleaved-Caspase-3, and Cleaved-Caspase-9 [7]. Bcl-2 family proteins play an important role in intrinsic apoptosis pathway [8]. These proteins are either antiapoptotic proteins such as Bcl-2 or pro-apoptotic proteins such as Bax, and the interactions among them may influence cell fate [9]. The Bcl-2 to Bax ratio is critical for determining whether apoptosis occurs [10]. A decrease in this ratio promotes the release of cytochrome $\mathrm{c}$ from the mitochondria into the cytosol, leading to the subsequent activation of Caspase- 3 and Caspase-9 [11]. Apoptosis has a beneficial effect on pancreatic $\beta$-cell dysfunction.

A new drug or method to obstruct the process of Min6 cell dysfunction is significant. Averrhoa carambola $L$. is a perennial herb widely distributed in Southeast Asia. Its roots have been employed in Traditional Chinese Medicine (TCM) for thousands of years. Averrhoa carambola $L$. is commonly used to treat headaches, vomiting, coughing and hangovers [12]. Furthermore, it is used as an appetite stimulant, a diuretic, and as an antidiarrheal and febrifugal agent [13]. In our previous work, we found that the extract obtained by decocting the roots of Averrhoa carambola L. had been used in the treatment of streptozotocin-induced diabetic mice [14], and reduced the expression levels of TLR4 and NF- $\kappa \mathrm{B}$ [15]. We also found that 2-dodecyl-6-methoxycyclohexa-2, 5-diene-1, 4-dione (DMDD) (Fig. 1), isolated from the roots of Averrhoa carambola L., had a beneficial effect on advanced glycation endproduct-mediated renal injury in type 2 diabetic KKAy mice [16]. However, the protective effect of DMDD against pancreatic $\beta$-cell line Min6 has never been reported. We investigated whether DMDD protected against PA-induced inflammation and apoptosis, and whether its mechanism of this protection was associated with inhibiting the TLR4-MyD88-NF- $\kappa$ B signaling pathway.

\section{Materials and Methods}

\section{Plant materials and extraction and isolation of DMDD}

The Averrhoa carambola L. plant material was obtained from Lingshan County, Guangxi Autonomous Region, China, in October 2012 and was identified by Lai Mao-xiang at Traditional Chinese Medicine Research Institute of Guangxi. The voucher specimen (No. 20121016) was deposited in the Guangxi Institute of Chinese Medicine \& Pharmaceutical Science herbarium (Guangxi, China). The isolation of DMDD was prepared using a method as described previously [17]. DMDD was dissolved in dimethyl sulfoxide (DMSO) at a concentration of $10 \mathrm{mmol} / \mathrm{l}$. In all tests, the DMDD stock solution was further diluted in cell culture medium by 100 fold or more, and $0.5 \%$ DMSO was used as a vehicle control in the untreated cells.

Cell culture

Min6 cells, purchased from the Committee on Type Culture Collection of Chinese Academy of Sciences (CTCCCAS, Shanghai, China), were maintained in Dulbecco's Modified Eagle Medium (DMEM) (GIBCO, New 


\section{Cellular Physiology Cell Physiol Biochem 2016;39:1705-1715 \begin{tabular}{l|l} 
and Biochemistry Published online: September 19, 2016 & $\begin{array}{l}\text { (c) } 2016 \text { The Author(s). Published by S. Karger AG, Basel } \\
\text { www.kargercom/cpb }\end{array}$
\end{tabular} \\ Xie et al.: Protective Effects of DMDD on Min6 Cells Dysfunction}

York, USA) supplemented with $10 \%$ fetal bovine serum (FBS) (GIBCO, New York, USA) and 1\% penicillin-streptomycin (Sigma-Aldrich, St. Louis, Missouri, USA) in a humidified incubator at $37^{\circ} \mathrm{C}$ with $5 \% \mathrm{CO}_{2}$.

\section{Cell viability analysis}

Fig. 1 Chemical structure of DMDD.

The cytotoxicity of DMDD was first measured by using a Cell Counting Kit-8 (CCK8) (Dojindo Laboratory, Kumamoto, Japan). Briefly, Min6 cells were seeded into a 96-well plate overnight and treated with concentrations ( $0 \mu \mathrm{mol} / \mathrm{l}, 10 \mu \mathrm{mol} / \mathrm{l}, 20 \mu \mathrm{mol} / \mathrm{l}, 30 \mu \mathrm{mol} / \mathrm{l}, 40 \mu \mathrm{mol} / \mathrm{l}$, and $50 \mu \mathrm{mol} / \mathrm{l})$ of DMDD. After incubation for $24 \mathrm{~h}$, cell survival was measured by using a CCK8 as described previously [18].

Next, Min6 cells were seeded into a 96-well plate overnight. Cells were pretreated with concentrations ( $5 \mu \mathrm{mol} / \mathrm{l}, 10 \mu \mathrm{mol} / \mathrm{l}, 15 \mu \mathrm{mol} / \mathrm{l}, 20 \mu \mathrm{mol} / \mathrm{l}, 25 \mu \mathrm{mol} / \mathrm{l}$ and $30 \mu \mathrm{mol} / \mathrm{l}$ ) of DMDD for $24 \mathrm{~h}$ and then exposed to $0.4 \mathrm{mmol} / \mathrm{l} \mathrm{PA}$ (dissolved in dimethyl sulfoxide (DMSO) at a concentration of $40 \mathrm{mmol} / \mathrm{l}$ and further diluted in cell culture medium by 100 fold) for $24 \mathrm{~h}$. 0.5\% DMSO was used as a vehicle control in the untreated cells. After treatment, cell viability was measured by using a CCK8 (Dojindo Laboratory, Japan) as described previously [18].

\section{Glucose-stimulated insulin secretion levels analysis}

Glucose-stimulated insulin secretion levels were measured by using an Insulin ELISA Kit. Briefly, Min6 cells were seeded into a 24-well plate overnight. Cells were pretreated with concentrations $(10 \mu \mathrm{mol} / \mathrm{l}$, $15 \mu \mathrm{mol} / \mathrm{l}$, and $20 \mu \mathrm{mol} / \mathrm{l}$ ) of DMDD for $24 \mathrm{~h}$ and then exposed to $0.4 \mathrm{mmol} / \mathrm{l} \mathrm{PA}$ for $24 \mathrm{~h}$. After treatment, cells were incubated for $1 \mathrm{~h}$ in glucose-free Krebs-Ringer Bicarbonate (KRB) buffer (115 mmol/l NaCl, 4.7 mmol/l KCl, $1.2 \mathrm{mmol} / \mathrm{MgSO}_{4}, 1.2 \mathrm{mmol} / \mathrm{KH}_{2} \mathrm{PO}_{4}, 20$ mmol/l NaHCO${ }_{3}, 16$ mmol/l HEPES, $2.56 \mathrm{mmol} / \mathrm{l}$ $\mathrm{CaCl}_{2}, 0.2 \% \mathrm{BSA}$ ) (all from Nanjing Jiancheng Bioengineering Research Institute, Nanjing, China). Afterward, cells were incubated for $1 \mathrm{~h}$ in KRB buffer with basal (2.8 mmol/l) and high glucose levels (16.7 mmol/l). Insulin levels were measured by using an Insulin ELISA Kit (Sigma-Aldrich, St. Louis, Missouri, USA) as described previously [19].

Inflammatory cytokines IL-6, TNF- $\alpha, M C P-1$ levels analysis

Inflammatory cytokines IL-6, TNF- $\alpha$, and MCP-1 levels in DMDD-pretreated Min6 cells were measured by using IL-6, TNF- $\alpha$, and MCP-1 ELISA Kits (all from Nanjing Jiancheng Bioengineering Research Institute, Nanjing, China) as previously described [20].

\section{Annexin V-FITC/PI Flow cytometric analysis}

The rate of apoptosis in PA-induced Min6 cells was measured by using the Annexin V-FITC/ PI Kit (Life Technologies, Carlsbad, CA, USA), and analyzed on a FACStar-Plus flow cytometer (Becton Dickinson, Franklin Lakes, NJ, USA) as previously described [21].

Hoechst 33342/ PI double-staining analysis

The numbers of apoptotic cells in PA-induced Min6 cells were also investigated by using the Hoechst 33342/PI double-staining Kit (Life Technologies, Carlsbad, CA, USA) as previously described [22], and cell images were captured using a fluorescence microscopy (Olympus, Tokyo, Japan). Apoptotic cells were counted using a cell counter under a fluorescence microscope at $200 \times$ magnifications, and 4 randomly selected fields in each group were used to estimate the average numbers of apoptotic cells.

\section{Transmission electron microscopy analysis}

Ultrastructure changes of apoptosis were observed using a transmission electron microscope (Hitachi, Tokyo, Japan). Transmission electron microscopy analysis was conducted as previously described [23].

\section{Relative quantitative real-time PCR analysis}

Total RNA was extracted by using RNAiso Plus kits (Takara Biotechnology Co. Ltd, Dalian, China) and cDNA was synthesized from RNA with a PrimeScript ${ }^{\mathrm{TM}}$ RT reagent Kit (Takara Biotechnology Co. Ltd, Dalian, China) as described previously [24]. RT-PCR was performed on an ABI Prism 7300 real-time thermocycler (Applied Biosystems, Foster City, CA, USA) using the TransScript ${ }^{\mathrm{TM}}$ SYBR® Green Master Mix kit (Takara 


\section{Cellular Physiology Cell Physiol Biochem 2016;39:1705-1715 \begin{tabular}{l|l|l} 
and Biochemistry Published $10.1159 / 000447871$ & (c) 2016 The Author(s). Published by S. Karger AG, Basel \\
www.karger.com/cpb
\end{tabular} Xie et al.: Protective Effects of DMDD on Min6 Cells Dysfunction}

Table 1. Primers information for RT-PCR

\begin{tabular}{llll}
\hline Gene & Forward primer $\left(5^{\prime}-3^{\prime}\right)$ & Reverse primer $\left(5^{\prime}-3^{\prime}\right)$ & Product size $(\mathrm{bp})$ \\
\hline TLR4 & CATGGATCAGAAACTCAGCAAAGTC & CATGCCATGCCTTGTCTTCA & $179 \mathrm{bp}$ \\
MyD88 & TACAGGTGGCCAGAGTGGAA & GCAGTAGCAGATAAAGGCATCGAA & $119 \mathrm{bp}$ \\
NF- $\kappa$ B & GAACGATAACCTTTGCAGGC & TTTCGATTCCGCTATGTGTG & $130 \mathrm{bp}$ \\
IL-6 & GACGTTTCAGAGGTTCTCAGAG & TAGTCCTTCCTACCCCAATTTCC & $180 \mathrm{bp}$ \\
TNF- $\alpha$ & CCCTCACACTCAGATCATCTTCT & GCTACGACGTGGGCTACAG & $176 \mathrm{bp}$ \\
MCP-1 & CCACAGCATGGACGAATTCA & AGCTTGCTTTGTGGCCTTCA & $154 \mathrm{bp}$ \\
Bax & CAGGATGCGTCCACCAAGAA & CGTGTCCACGTCAGCAATCA & $102 \mathrm{bp}$ \\
Bcl-2 & AGCGTCAACAGGGAGATGTC & TTCCACAAAGGCATCCCAGC & $389 \mathrm{bp}$ \\
$\beta$-actin & AACCCTAAGGCCAACCGTGAAAAG & TCATGAGGTAGTCTGTCAGGT & $186 \mathrm{bp}$ \\
\hline
\end{tabular}

Biotechnology Co. Ltd, Dalian, China) as described previously [25]. $\beta$-actin was used as an endogenous control. The amount of genes expression was normalized by the $2^{-\Delta \Delta \mathrm{CT}}$ relative quantitative method. The primers information for PCR is given in Table. 1.

\section{Western blotting analysis}

Protein isolation and western blot was conducted as previously described [26]. Proteins were detected with primary antibodies to TLR4, MyD88, NF- $\kappa \mathrm{B}, \mathrm{I} \kappa \mathrm{B} \alpha$, Cleaved-Caspase-3, -8, -9, Bax, and Bcl-2 (all from Cell Signaling Technology, Boston, MA, USA).

\section{Statistical analysis}

Statistic analysis was performed using the SPSS 17 statistical program (SPSS Inc., Chicago, IL, USA). One-way analysis of variance (ANOVA) was used to compare the means among different groups. Multiple comparisons between the groups were performed using $\mathrm{S}-\mathrm{N}-\mathrm{K}$ method. The data are presented as the mean \pm SD. ${ }^{*} P \leq 0.05 ;{ }^{* *} P \leq 0.01 ;{ }^{* * *} P \leq 0.001$.

\section{Results}

DMDD increases cell viability in PA-induced Min6 cells

As shown in Fig. 2(a), DMDD showed a non-toxic range at concentrations of 0-30 $\mu \mathrm{mol} / \mathrm{l}$ for $24 \mathrm{~h}$. As shown in Figure. 2(b), cell viability was significantly lower in cells only treated with PA, and this decrease was prevented by pretreating cells with DMDD. No significant difference was found between the $5 \mu \mathrm{mol} / \mathrm{l}$ DMDD-pretreated group and the PA group. There was a similar viability among the $20 \mu \mathrm{mol} / \mathrm{l}, 25 \mu \mathrm{mol} / \mathrm{l}$ and $30 \mu \mathrm{mol} / \mathrm{l}$ DMDD-pretreated groups. Therefore, we used the low-, medium-, and high-concentrations of DMDD (10 $\mu \mathrm{mol} / \mathrm{l}, 15 \mu \mathrm{mol} / \mathrm{l}$, and $20 \mu \mathrm{mol} / \mathrm{l}$ ) for the following studies with cultured Min 6 cells.

DMDD increases glucose-stimulated insulin secretion levels in PA-induced Min6 cells

As shown in Fig. 3, glucose-stimulated insulin secretion levels were significantly lower in cells only exposed to PA, and this decrease was prevented by pretreating cells with DMDD at high glucose levels (16.7 mmol/l). No significant difference was found between basal (2.8 $\mathrm{mmol} / \mathrm{l})$ glucose-stimulated groups.

DMDD reduces inflammatory cytokines levels in PA-induced Min6 cells

As shown in Fig. 4(a), the expressions of IL-6, TNF- $\alpha$, and MCP-1 mRNA were up-regulated in PA group cells. However, the expressions of these genes were down-regulated in DMDD-pretreated group cells. As shown in Fig. 4(b), these inflammatory cytokines levels were significantly higher in cells only exposed to PA, and this increase was prevented by pretreating cells with DMDD.

DMDD protects Min6 cell against PA-induced apoptosis

The representative images for AnnexinV-FITC/PI flow cytometry analysis were presented in Fig. 5(a). As shown in Fig. 5(d), the rate of apoptosis was significantly higher 
Fig. 2. DMDD increases cell viability in PA-induced Min6 cells. (a) The cytotoxicity of DMDD on Min6 cells. (b) DMDD increases cell viability in PA-induced Min6 cells. All data are presented as the mean \pm SD. $(n=3) .{ }^{*} P \leq 0.05$, compared with untreated group. ${ }^{*} P \leq 0.05$; ** $P \leq 0.01$; $* * * P \leq 0.001$, compared with PA group.

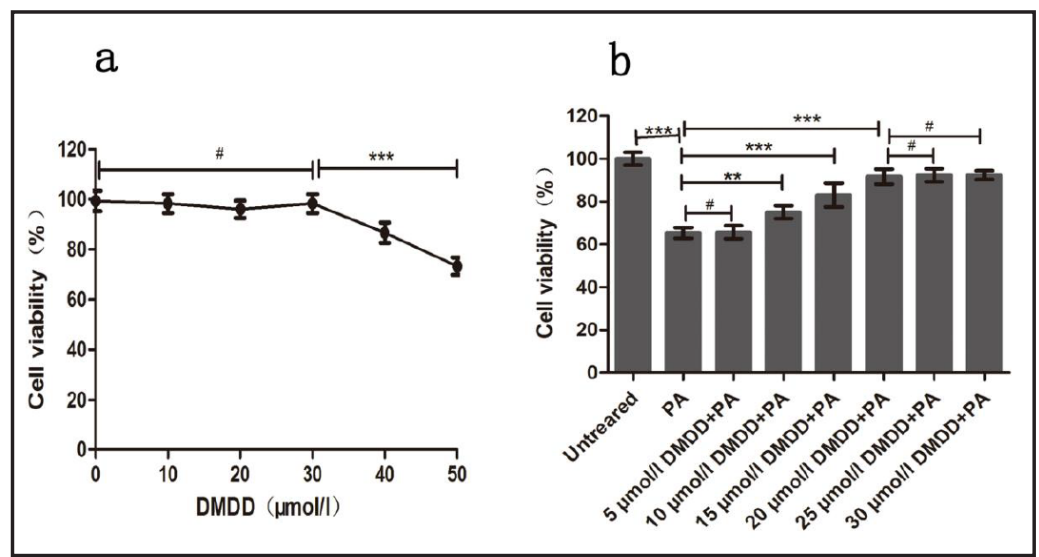

Fig. 3. DMDD increases glucose-stimulated insulin secretion levels in PA-induced Min6 cells. All data are presented as the mean $\pm \mathrm{SD}$. $(n=3)$. ${ }^{*} P \leq 0.05$; ${ }^{* *} P \leq 0.01$; ${ }^{* * *} P \leq 0.001$.

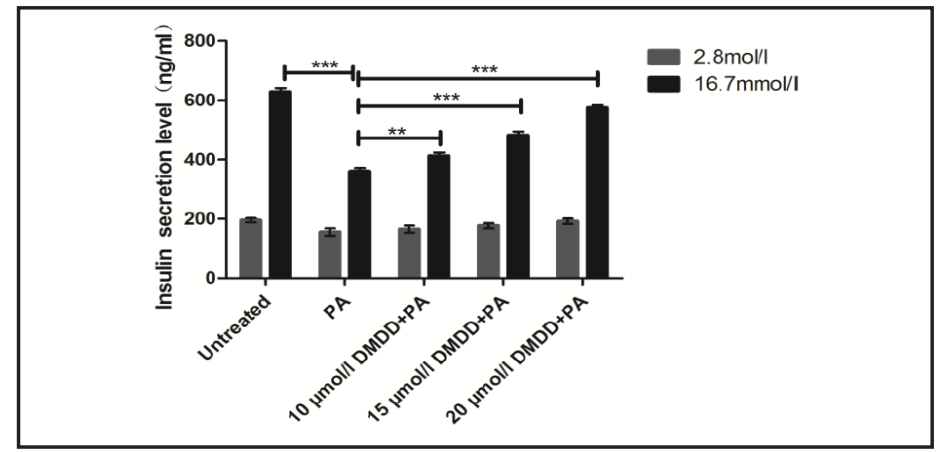

Fig. 4. DMDD reduces inflammatory cytokines levels in PA-induced Min6 cells. (a) DMDD inhibits the expressions of IL-6, TNF- $\alpha$ and MCP1 mRNA in PA-induced Min6 cells. (b) DMDD inhibits the inflammatory cytokines IL-6, TNF- $\alpha$ and MCP-1 generations in PA-induced Min6 cells. All Data are presented as the mean \pm SD. $(n=3) .{ }^{*} P \leq 0.05 ;{ }^{* *} P \leq 0.01$; $* * * P \leq 0.001$.

in cells only exposed to PA, and this increase was prevented by pretreating cells with DMDD.

The representative images for Hoechst 33342/PI double-staining analysis were presented in Fig. 5(b). High blue fluorescent indicated early apoptotic cells (bright blue arrow), and low blue indicated live cells (azury arrow). While high red represented necrotic cells (pink arrow), and low pink represented late apoptotic cells (bright pink arrow). As shown in Fig. 5(e), the numbers of

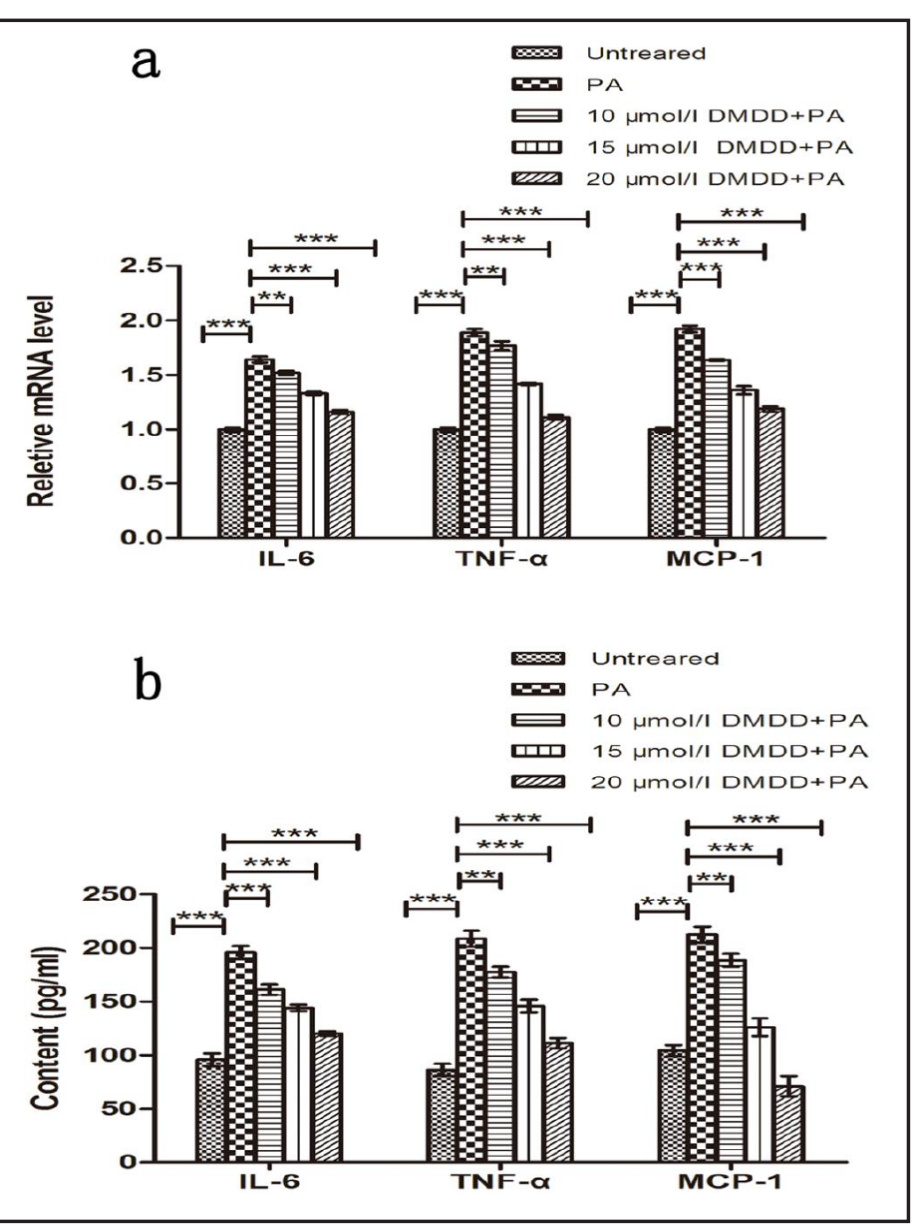




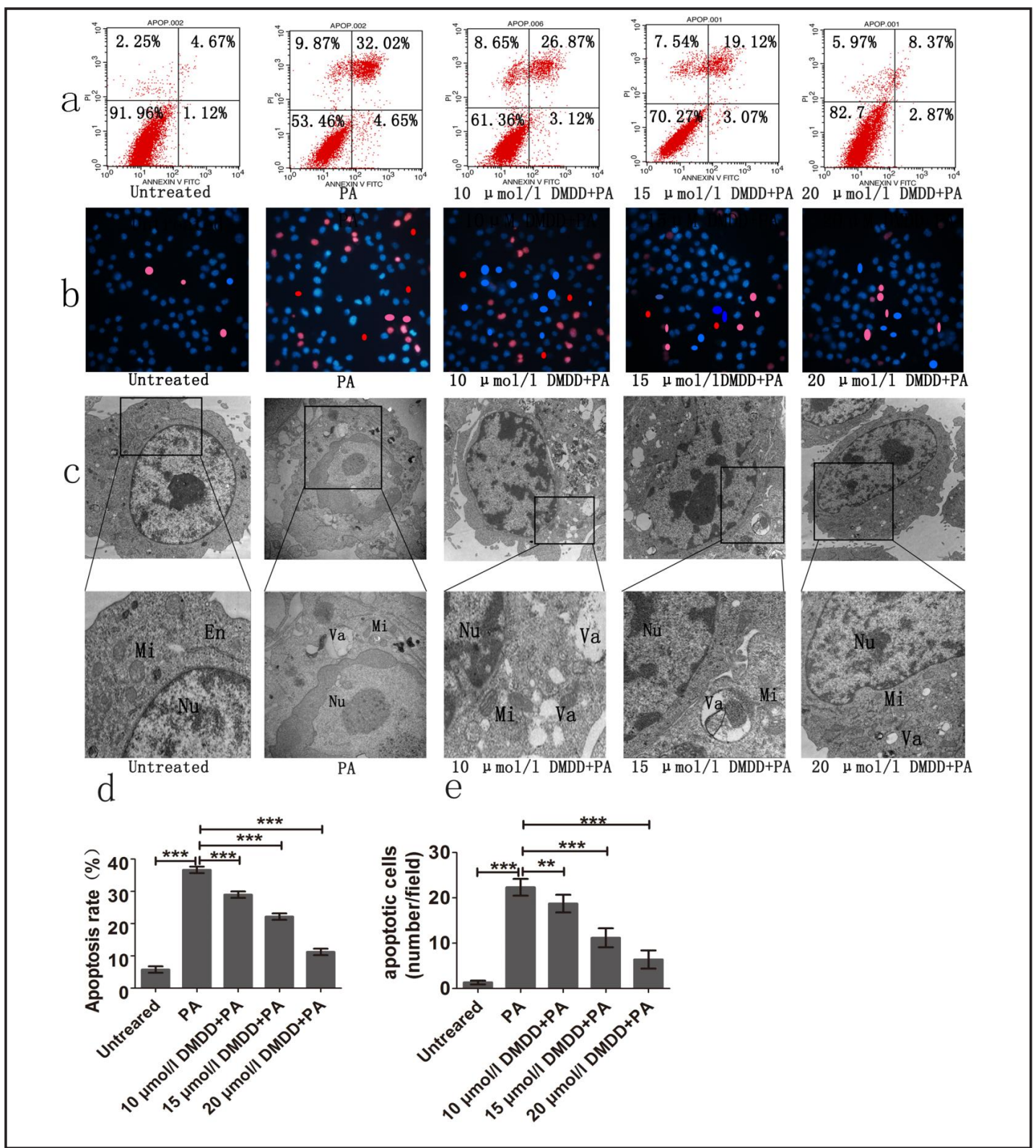

Fig. 5. DMDD protects Min6 cell against PA-induced apoptosis. (a) The representative images for AnnexinV-FITC/PI flow cytometry analysis. (b) The representative images (magnifications: $\times 200$ ) for Hoechst 33342/PI double-staining analysis. (c) The representative images (magnifications: $\times 15000$ and magnifications: $\times 30000$ ) for transmission electron microscopy analysis. Nu: nuclear; Mi: mitochondria; En: endoplasmic reticulum; Va: cytoplasm vacuolization. (d) DMDD decreases the rate of apoptosis in PA-induced Min6 cells using AnnexinV-FITC/PI flow cytometry analysis. (e) DMDD decreases the numbers of apoptotic cells using Hoechst 33342/ PI double-staining analysis. All data are presented as the mean \pm SD. $(n=3)$. ${ }^{*} P \leq 0.05$; ** $P \leq 0.01 ;{ }^{* * *} P \leq 0.001$.

apoptotic cells, including early and late apoptotic cells, were significantly higher in cells only exposed to PA, and this increase was prevented by pretreating cells with DMDD.

As shown in Fig. 5(c), PA group cells displayed cell shrinkage, irregular nuclear outline, condensed chromosomes in apoptotic cells, a loose endoplasmic reticulum, morphologically abnormal mitochondrial structures, and cytoplasm vacuolization. The ultrastructural changes of apoptosis in the DMDD-pretreated group cells appeared to be improved compared with PA group cells. 
Fig. 6. DMDD inhibits the expressions of Cleaved-Caspase-3, -8, -9, and increases the Bcl-2/Bax ratio in PA-induced Min6 cells. $(a, b)$ DMDD inhibits the expression of Bax mRNA and increases the expression of Bcl-2 mRNA. (c, d, e, f, g, h, i, j) DMDD inhibits the expressions of Cleaved-Caspase-3,-8, -9 proteins, and increases the Bcl-2/ Bax rate. All data are presented as the mean $\pm S D$. $(n=3) .{ }^{*} P \leq 0.05$; ${ }^{* *} P \leq 0.01$; ${ }^{* * *} P \leq$ 0.001 .

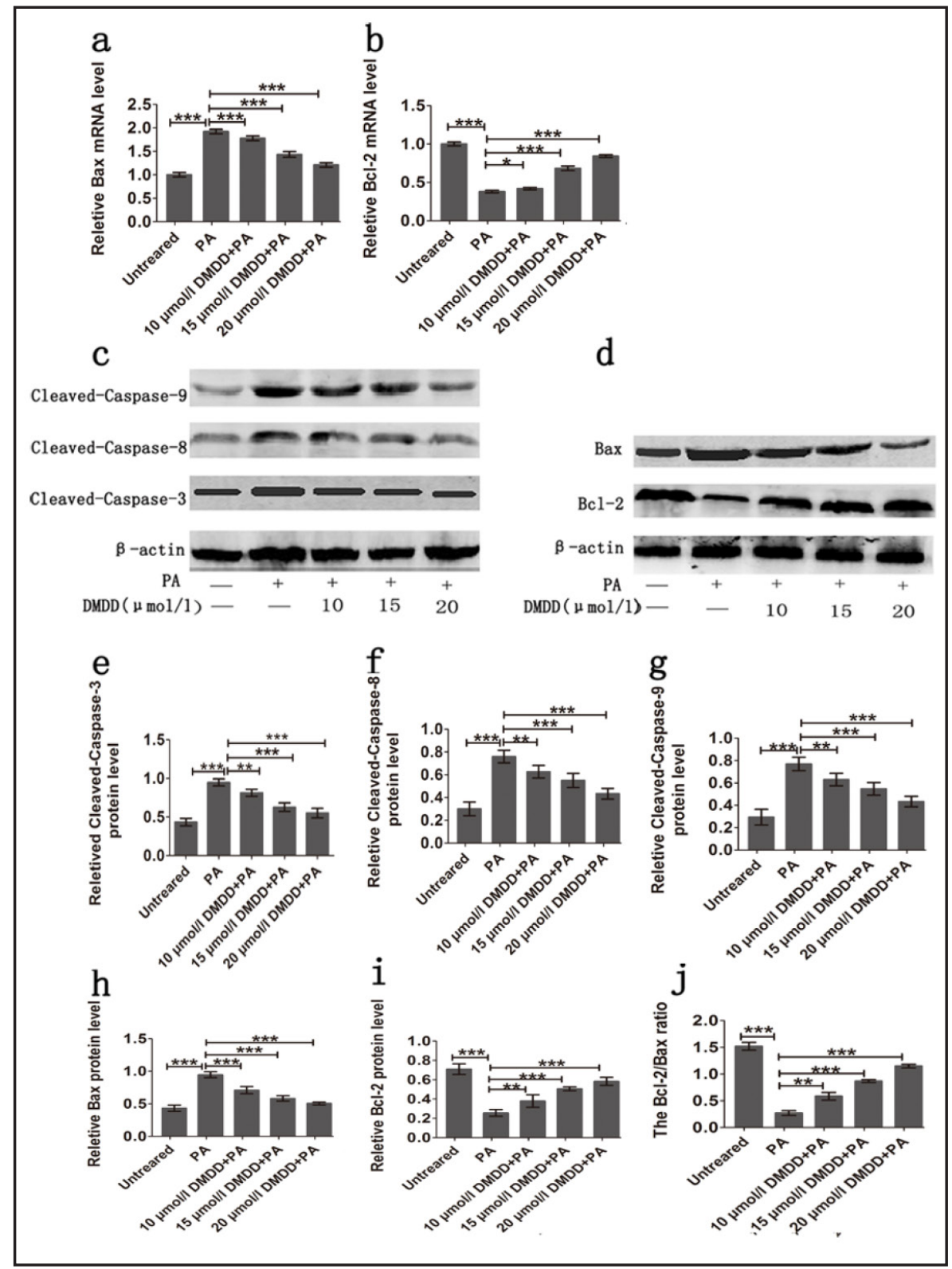

DMDD inhibits the expressions of Cleaved-Caspase-3, -8, -9, and increases the Bcl-2/Bax ratio in PA-induced Min6 cells

As shown in Fig. 6(c, e, f, g), the expressions of Cleaved-Caspase-3, -8, and -9 proteins were up-regulated in cells only exposed to PA. However, the expressions of these proteins were down-regulated in cells pretreated with DMDD. As shown in Fig. 6(a, b, d, h, I, j), the expressions of Bax mRNA and protein were up-regulated whereas the expressions of Bcl-2 mRNA and protein were down-regulated in PA group cells. However, the expressions of Bax mRNA and protein were down-regulated whereas the expressions of $\mathrm{Bcl}-2 \mathrm{mRNA}$ and protein were up-regulated in cells pretreated with DMDD. The Bcl-2/Bax ratio was significantly lower in cells only exposed to PA, and this decrease was prevented by pretreating cells with DMDD.

DMDD inhibits the TLR4-MyD88-NF- $\mathrm{B}$ B signaling pathway in PA-induced Min6 cells

TAK-242, a TLR4 pathway inhibitor, was a control drug to determine whether the protective effects of DMDD against PA-induced inflammation and apoptosis in Min6 cells and to further explore the impact of DMDD on the downstream targets of the TLR4-MyD88- 

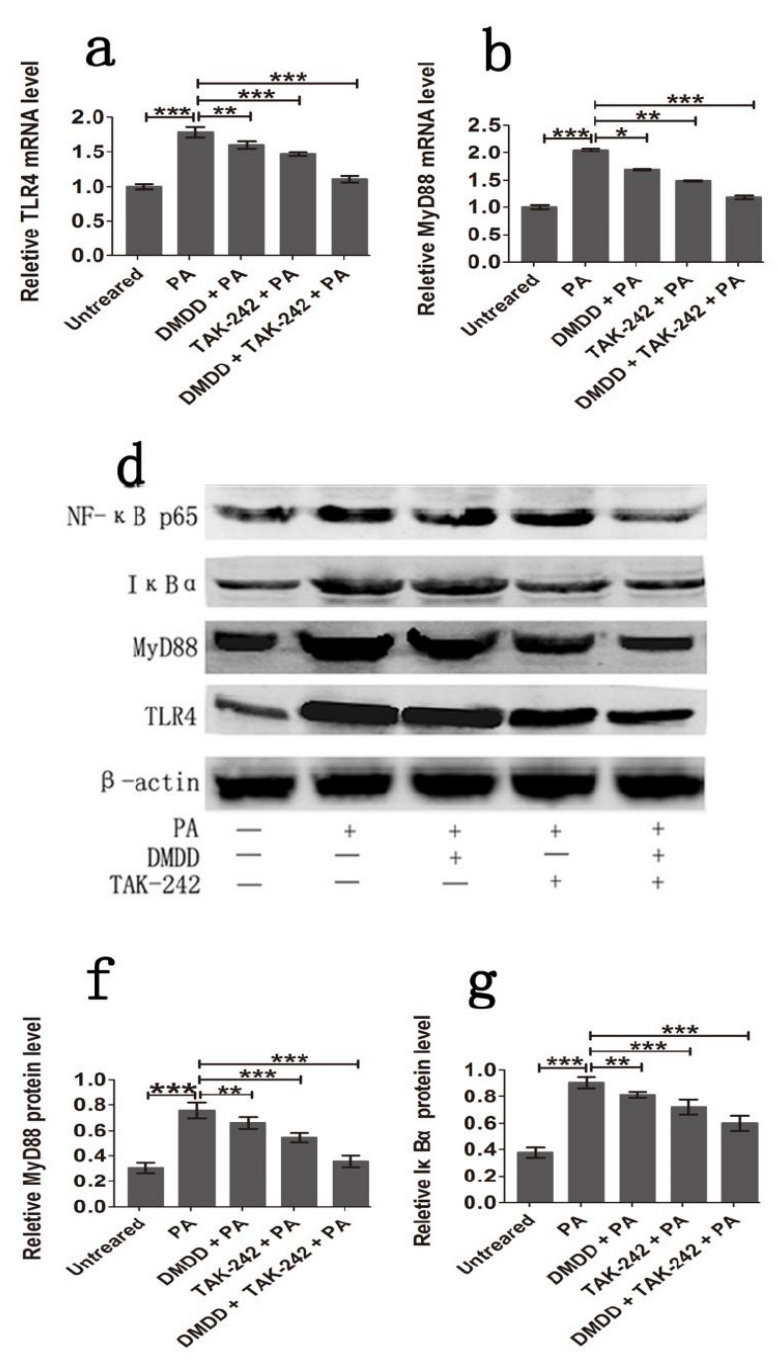
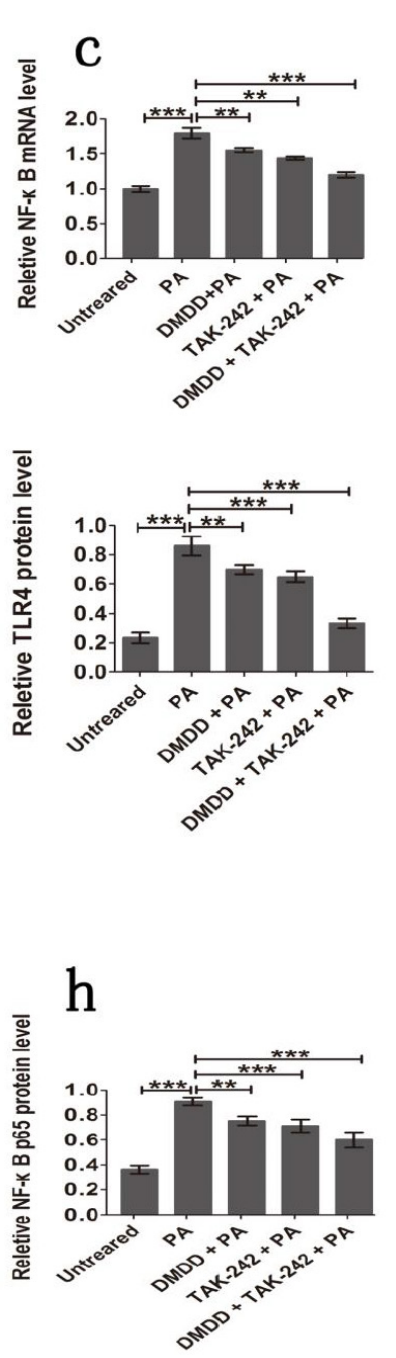

Fig. 7. DMDD inhibits the expressions of TLR4, MyD88 and NF- $\kappa$ B in PA-induced Min6 cells. PA group: PA (0.4 mmol/l). DMDD-pretreated group: DMDD $(20 \mu \mathrm{mol} / \mathrm{l})+$ PA (0.4 mmol/l). TAK-242-pretreated group: TAK-242 (1 ng/l) + PA (0.4 mmol/l). DMDD and TAK-242-pretreated group: DMDD (20 $\mu \mathrm{mol} / \mathrm{l})+$ TAK-242 (1 ng/l) + PA (0.4 mmol/l). (a, b, c) DMDD inhibits the expressions of TLR4, MyD88 and NF- $\kappa$ B mRNA in PA-induced Min6 cells. (d, e, f, g, h) DMDD inhibits the expressions of TLR4, MyD88, I $\kappa \mathrm{B} \alpha$ and NF- $\kappa \mathrm{B}$ proteins in PA-induced Min6 cells. All data are presented as the mean \pm SD. $(n=3)$. ${ }^{*} P \leq 0.05 ;{ }^{* *} P \leq 0.01 ;{ }^{* * *} P \leq 0.001$.

NF $\kappa$ B signaling pathway. As shown in Fig. 7, the expressions of TLR4, MyD88, and NF- $\kappa \mathrm{B}$ mRNA and proteins were up-regulated in PA group cells. However, the expressions of these genes and proteins were down-regulated in DMDD-pretreated group cells and TAK-242pretreated group cells. DMDD and TAK-242 also suppressed the phosphorylation of $\mathrm{I} \kappa \mathrm{B} \alpha$, which leads to $\mathrm{I} \kappa \mathrm{B} \alpha$ degradation and release of NF- $\kappa \mathrm{B}$.

\section{Discussion}

Natural products derived from plants have long been used in folk medicine, making the compounds derived from these plants good candidates for new therapeutic strategies. In our previous work, we provided evidence that the extract obtained by decocting the roots of 


\section{Cellular Physiology Cell Physiol Biochem 2016;39:1705-1715

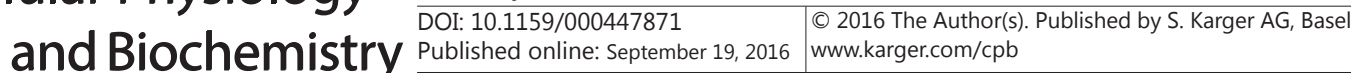 \\ Xie et al.: Protective Effects of DMDD on Min6 Cells Dysfunction}

Averrhoa carambola L. had a beneficial effect on streptozotocin-induced diabetic mice [14], and reduced the expression levels of TLR4 and NF- $\mathrm{KB}$ [15]. We also isolated 2-dodecyl-6methoxycyclohexa-2, 5-diene-1, 4-dione (DMDD) from the roots of Averrhoa carambola L., and found it beneficial on advanced glycation end-product-mediated renal injury in type 2 diabetic KKAy mice [16]. However, the protective effect of DMDD against pancreatic $\beta$-cell line Min6 has never been reported. In this work, we provide evidence for and mechanistic insight into how DMDD exerts a beneficial effect on pancreatic $\beta$-cell line Min 6 dysfunction.

Inflammation is believed to be a key feature in the pathogenesis of diabetes and cytokines are known to contribute to the failure and death of beta cells [27]. The immune system is activated by TNF- $\alpha$, and leukotrienes and platelet-activating factor are then synthesized and mobilized, which results in an inflammatory response [28]. An extended duration of hyperglycemia produces glycation products that cause excess IL- 6 synthesis and initiate $\beta$-cell dysfunction. Our work indicated that DMDD reduced PA-induced inflammation damage in Min6 cells by reducing the levels of IL-6, TNF- $\alpha$, and MCP-1.

Apoptosis is widely recognized to play an important role in the pathogenesis of Min6 cell dysfunction. Apoptosis can be induced by either the intrinsic or the extrinsic pathway. Caspase- 8 was the initiator caspase of the extrinsic pathway. Caspase- 3 and Caspase- 9 were the initiator caspase of the intrinsic pathway. Bcl-2 family members play an important role in intrinsic apoptosis pathway. The ratio of $\mathrm{Bcl}-2$ to Bax is critical for determining whether apoptosis occurs. A decrease in this ratio promotes the release of cytochrome $c$ from the mitochondria into the cytosol, leading to the subsequent activation of Caspase- 9 and Caspase-3. Our work indicated that DMDD affected the extrinsic apoptotic pathway by suppressing Caspase-8, and affected the intrinsic apoptotic pathway by suppressing CleavedCaspase- 3 and Cleaved-Caspase-9, and increasing the Bcl-2/Bax ratio. DMDD protected Min6 cell against PA-induced apoptosis involving both the extrinsic and intrinsic signaling pathways.

Numerous studies have shown that PA induces Min6 cell dysfunction by the TLR4 pathway [29]. With the stimulation of PA, TLR4 and MyD88 are activated, which leads to the degradation of $\mathrm{I} \kappa \mathrm{B} \alpha$ proteins and the subsequent translocation of the transcription nuclear factor $\kappa \mathrm{B}(\mathrm{NF}-\kappa \mathrm{B})$ [30]. In our work, we used TAK-242, a TLR4 pathway inhibitor, as a control drug to determine whether the protective effects of DMDD against PA-induced inflammation and apoptosis in Min6 cells and to further explore the impact of DMDD on the downstream targets of the TLR4-MyD88-NF- $\kappa$ B signaling pathway. The expression of TLR4, MyD88, and NF- $\kappa$ B were down-regulated in DMDD-pretreated Min 6 cells and TAK-242-pretreated group cells. Our work indicated that DMDD protected Min6 cells against PA-induced inflammation and apoptosis in Min6 cells by inhibiting the TLR4-MyD88-NF- $\kappa$ B signaling pathway.

Collectively, we provide evidence that DMDD protects Min6 cells against PA-induced inflammation and apoptosis, and its mechanism of this protection is associated with inhibiting the TLR4-MyD88-NF- $\kappa$ B signaling pathway. DMDD may be a promising candidate for the treatment of pancreatic $\beta$-cell Min6 dysfunction.

\section{Acknowledgments}

This work was supported by the National Natural Science Foundation of China (No.81360129, 81460205, 81160533), the State Key Laboratory Cultivation Base for the Chemistry and Molecular Engineering of Medicinal Resources of the Ministry of Science and Technology of China (CMEMR2014-B01), the Guangxi Key Laboratory for Metabolic Disease Research (2012-181h-02), and the Scientific Research and Technology Development Plan of Qingxiu District of Nanning, Guangxi (2013S12).

\section{Disclosure Statement}

All authors declare that there is no duality of interest associated with this manuscript. 


\section{Cellular Physiology Cell Physiol Biochem 2016;39:1705-1715

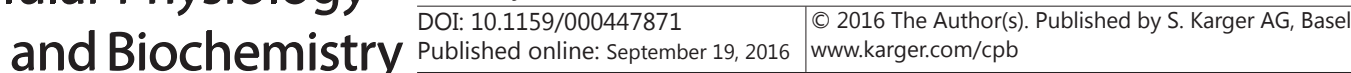 \\ Xie et al.: Protective Effects of DMDD on Min6 Cells Dysfunction}

\section{References}

1 Panse M, Gerst F, Kaiser G, Teutsch CA, Dolker R, Wagner R, Haring HU, Ullrich S: Activation of extracellular signal-regulated protein kinases 1 and 2 (ERK1/2) by free fatty acid receptor 1 (FFAR1/GPR40) protects from palmitate-induced beta cell death, but plays no role in insulin secretion. Cell Physiol Biochem 2015;35:1537-1545.

2 Badr BM, Moustafa NA, Eldien HM, Mohamed AO, Ibrahim HM, El-Elaimy IA, Mahmoud MH, Badr G: Increased levels of type 1 interferon in a type 1 diabetic mouse model induce the elimination of $\mathrm{B}$ cells from the periphery by apoptosis and increase their retention in the spleen. Cell Physiol Biochem 2015;35:137-147.

3 Cheng K, Delghingaro-Augusto V, Nolan CJ, Turner N, Hallahan N, Andrikopoulos S, Gunton JE: High passage MIN6 cells have impaired insulin secretion with impaired glucose and lipid oxidation. PLoS One 2012; 7:e40868.

4 Deas E, Piipari K, Machhada A, Li A, Gutierrez-del-Arroyo A, Withers DJ, Wood NW, Abramov AY: PINK1 deficiency in beta-cells increases basal insulin secretion and improves glucose tolerance in mice. Open Biol 2014;4:140051.

5 Fan HQ He W, Xu KF, Wang ZX, Xu XY, Chen H: FTO Inhibits Insulin Secretion and Promotes NFkappaB Activation through Positively Regulating ROS Production in Pancreatic beta cells. PLoS One 2015;10:e0127705.

6 Fernandez-Ruiz R, Vieira E, Garcia-Roves PM, Gomis R: Protein tyrosine phosphatase-1B modulates pancreatic beta-cell mass. PLoS One 2014;9:e90344.

7 Fuentes L, Wouters K, Hannou SA, Cudejko C, Rigamonti E, Mayi TH, Derudas B, Pattou F, ChinettiGbaguidi G, Staels B, Paumelle R: Downregulation of the tumour suppressor p16INK4A contributes to the polarisation of human macrophages toward an adipose tissue macrophage (ATM)-like phenotype. Diabetologia 2011;54:3150-3156.

8 Gunton JE, Sisavanh M, Stokes RA, Satin J, Satin LS, Zhang M, Liu SM, Cai W, Cheng K, Cooney GJ, Laybutt DR, So T, Molero JC, Grey ST, Andres DA, Rolph MS, Mackay CR: Mice deficient in GEM GTPase show abnormal glucose homeostasis due to defects in beta-cell calcium handling. PLoS One 2012;7:e39462.

9 Gurevitch D, Boura-Halfon S, Isaac R, Shahaf G, Alberstein M, Ronen D, Lewis EC, Zick Y: Elimination of negative feedback control mechanisms along the insulin signaling pathway improves beta-cell function under stress. Diabetes 2010;59:2188-2197.

10 Hill JA, Szabat M, Hoesli CA, Gage BK, Yang YH, Williams DE, Riedel MJ, Luciani DS, Kalynyak TB, Tsai K, Ao Z, Andersen RJ, Warnock GL, Piret JM, Kieffer TJ, Johnson JD: A multi-parameter, high-content, highthroughput screening platform to identify natural compounds that modulate insulin and Pdx1 expression. PLoS One 2010;5:e12958.

11 Hraha TH, Bernard AB, Nguyen LM, Anseth KS, Benninger RK: Dimensionality and size scaling of coordinated $\mathrm{Ca}(2+)$ dynamics in MIN6 beta-cell clusters. Biophys J 2014;106:299-309.

12 Jia L, Xing J, Ding Y, Shen Y, Shi X, Ren W, Wan M, Guo J, Zheng S, Liu Y, Liang X, Su D: Hyperuricemia causes pancreatic beta-cell death and dysfunction through NF-kappaB signaling pathway. PLoS One 2013;8:e78284.

13 Keller AC, Ma J, Kavalier A, He K, Brillantes AM, Kennelly EJ: Saponins from the traditional medicinal plant Momordica charantia stimulate insulin secretion in vitro. Phytomedicine 2011;19:32-37.

14 Xu X, Liang T, Wen Q, Lin X, Tang J, Zuo Q, Tao L, Xuan F, Huang R: Protective effects of total extracts of Averrhoa carambola L. (Oxalidaceae) roots on streptozotocin-induced diabetic mice. Cell Physiol Biochem 2014;33:1272-1282.

15 Xu X, Liang T, Lin X, Wen Q Liang X, Li W, Qin F, Zheng N, Ming J, Huang R: Effect of the Total Extract of Averrhoacarambola (Oxalidaceae) Root on the Expression Levels of TLR4 and NF-kappaB in Streptozotocin-Induced Diabetic Mice. Cell Physiol Biochem 2015;36:2307-2316.

16 Zheng N, Lin X, Wen Q Kintoko, Zhang S, Huang J, Xu X, Huang R: Effect of 2-dodecyl-6-methoxycyclohexa2,5-diene-1,4-dione, isolated from Averrhoa carambola L. (Oxalidaceae) roots, on advanced glycation endproduct-mediated renal injury in type 2 diabetic KKAy mice. Toxicol Lett 2013;219:77-84.

17 Wen Q Lin X, Liu Y, Xu X, Liang T, Zheng N, Kintoko, Huang R: Phenolic and lignan glycosides from the butanol extract of Averrhoa carambola L. root. Molecules 2012;17:12330-12340. 


\section{Cellular Physiology Cell Physiol Biochem 2016;39:1705-1715 \begin{tabular}{ll|l} 
DOI: 10.1159/000447871 & $\begin{array}{l}\text { O 2016 The Author(s). Published by S. Karger AG, Basel } \\
\text { www.karger.com/cpb }\end{array}$
\end{tabular} \\ Xie et al.: Protective Effects of DMDD on Min6 Cells Dysfunction}

18 Nakatsu D, Horiuchi Y, Kano F, Noguchi Y, Sugawara T, Takamoto I, Kubota N, Kadowaki T, Murata M: L-cysteine reversibly inhibits glucose-induced biphasic insulin secretion and ATP production by inactivating PKM2. Proc Natl Acad Sci U S A 2015;112:E1067-1076.

19 Nile DL, Brown AE, Kumaheri MA, Blair HR, Heggie A, Miwa S, Cree LM, Payne B, Chinnery PF, Brown L, Gunn DA, Walker M: Age-related mitochondrial DNA depletion and the impact on pancreatic Beta cell function. PLoS One 2014;9:e115433.

20 Sato Y, Inoue M, Yoshizawa T, Yamagata K: Moderate hypoxia induces beta-cell dysfunction with HIF-1independent gene expression changes. PLoS One 2014;9:e114868.

21 Takahashi I, Ohashi K, Nata K: Involvement of heparan sulfate 3-0-sulfotransferase isoform-1 in the insulin secretion pathway. J Diabetes Investig 2012;3:362-370.

22 Watson ML, Macrae K, Marley AE, Hundal HS: Chronic effects of palmitate overload on nutrient-induced insulin secretion and autocrine signalling in pancreatic MIN6 beta cells. PLoS One 2011;6:e25975.

23 Zhou J, Li W, Xie Q, Hou Y, Zhan S, Yang X, Xu X, Cai J, Huang Z: Effects of simvastatin on glucose metabolism in mouse MIN6 cells. J Diabetes Res 2014;2014:376570.

24 Valacchi G, Sticozzi C, Belmonte G, Cervellati F, Demaude J, Chen N, Krol Y, Oresajo C: Vitamin C Compound Mixtures Prevent Ozone-Induced Oxidative Damage in Human Keratinocytes as Initial Assessment of Pollution Protection. PLoS One 2015;10:e0131097.

25 Chowdhury S, Grimm L, Gong YJ, Wang B, Li B, Srikant CB, Gao ZH, Liu JL: Decreased 11betaHydroxysteroid Dehydrogenase 1 Level and Activity in Murine Pancreatic Islets Caused by Insulin-Like Growth Factor I Overexpression. PLoS One 2015;10:e0136656.

26 Rajan S, Dickson LM, Mathew E, Orr CM, Ellenbroek JH, Philipson LH, Wicksteed B: Chronic hyperglycemia downregulates GLP-1 receptor signaling in pancreatic beta-cells via protein kinase A. Mol Metab 2015;4:265-276.

27 Yin DD, Zhang EB, You LH, Wang N, Wang LT, Jin FY, Zhu YN, Cao LH, Yuan QX, De W, Tang W: Downregulation of lncRNA TUG1 affects apoptosis and insulin secretion in mouse pancreatic beta cells. Cell Physiol Biochem 2015;35:1892-1904.

28 Yamashiro K, Sasano T, Tojo K, Namekata I, Kurokawa J, Sawada N, Suganami T, Kamei Y, Tanaka H, Tajima N, Utsunomiya K, Ogawa Y, Furukawa T: Role of transient receptor potential vanilloid 2 in LPS-induced cytokine production in macrophages. Biochem Biophys Res Commun 2010;398:284-289.

29 Balasubramanian R, Maruoka H, Jayasekara PS, Gao ZG, Jacobson KA: AMP-activated protein kinase as regulator of P2Y(6) receptor-induced insulin secretion in mouse pancreatic beta-cells. Biochem Pharmacol 2013;85:991-998.

30 Lan H, Lin HV, Wang CF, Wright MJ, Xu S, Kang L, Juhl K, Hedrick JA, Kowalski TJ: Agonists at GPR119 mediate secretion of GLP-1 from mouse enteroendocrine cells through glucose-independent pathways. $\mathrm{Br} \mathrm{J}$ Pharmacol 2012;165:2799-2807. 